\title{
Characterization of bacterial endophytes from the roots of native and cultivated Brazil nut trees (Bertholletia excelsa)
}

\author{
Patrícia Bombonati CHALITA ${ }^{1}$, Eliane do Nascimento Cunha FARIAS², \\ Ismaele Breckenfeld da COSTA ${ }^{3}$, Brenda Ferreira SOUSA ${ }^{4 \S}$, Marco Antônio Oliveira dos SANTOS ${ }^{1}$, \\ Teresinha Costa Silveira de ALBUQUERQUE ${ }^{2}$, Marcos José Salgado VITAL ${ }^{1}$, Krisle da SILVA ${ }^{5 *}$ ๑ \\ Universidade Federal de Roraima (UFRR), Av. Enê Garcez, 2413, Aeroporto, 69.304-000 Boa Vista, RR, Brasil. \\ Embrapa Roraima, Rodovia BR-174, Km 8, Distrito Industrial, 69301-970 Boa Vista, RR, Brasil \\ Faculdade Roraimense de Ensino Superior, Av. Presidente Juscelino Kubitscheck 300, Canarinho, 69306-535 Boa Vista, RR, Brasil \\ ${ }^{4}$ Instituro Federal de Roraima, Av. Glaycon de Paiva 2496, Pricumã, 69.303-340 Boa Vista, RR, Brasil \\ Embrapa Florestas, Estrada da Ribeira, Km 111, Parque Monte Castelo, 83411-000 Colombo, PR, Brasil \\ In memorian \\ * Corresponding author: krisle.silva@embrapa.br; (D https://orcid.org/0000-0002-2512-9519
}

\section{ABSTRACT}

Brazil nut is a very important nontimber forest product in the Amazon region. Propagation of this tree still represents a challenge due to slow and uneven seed germination. In this context, plant growth-promoting bacteria can facilitate the process of propagation. The aims of this study were to isolate and characterize endophytic bacteria from the roots of Brazil nut trees in native terra firme forest and cultivation areas in northern Brazil, and to identify mechanisms by which bacteria act in plant growth promotion. Overall, 90 bacterial isolates were obtained from the roots of Brazil nut trees in monoculture, agroforestry and native forest areas by using different semisolid media. The isolates were characterized by sequencing the $16 \mathrm{~S}$ rRNA gene. Plant growth-promoting characteristics were evaluated by the presence of the nifH gene, aluminum phosphate solubilization and the production of indole compounds. The isolates were affiliated with 18 genera belonging to 5 different classes ( $\alpha$-Proteobacteria, $\beta$-Proteobacteria, $\gamma$-Proteobacteria, Bacilli and Actinobacteria). The genus Bacillus was predominant in the forest and monoculture areas. Fourteen isolates presented the nifH gene. Most of the bacteria were able to solubilize aluminum phosphate and synthetize indole compounds. The results indicated high diversity of endophytic bacteria present among the roots of Brazil nut trees, mainly in the agroforestry area, which could be related to soil attributes. Among the 90 isolates, the 22 that presented the best results regarding plant growth promotion traits were good candidates for testing in seedling production of Brazil nut trees.

KEYWORDS: 16S rRNA, phosphate solubilization, indole compounds, biological nitrogen fixation, plant growth-promotion bacteria, Amazon

\section{Caracterização de bactérias endofíticas de raízes de castanha-do-Brasil (Bertholletia excelsa) em habitats nativos e cultivados}

\section{RESUMO}

A castanha-do-brasil é um produto florestal não madeireiro muito importante na região amazônica. A propagação desta árvore ainda representa um desafio, devido ao lento e irregular processo de germinação das sementes. Neste contexto, bactérias promotoras do crescimento vegetal podem facilitar o processo de propagaçáo. O objetivo deste estudo foi isolar e caracterizar bactérias endofíticas em raízes de castanha-do-Brasil em floresta de terra firme e em áreas cultivadas no norte do Brasil, e identificar alguns mecanismos de promoçáo do crescimento vegetal executados por essas bactérias. No total, 90 isolados bacterianos foram obtidos de raízes de castanha-do-Brasil em monocultura, agrofloresta e floresta nativa, usando diferentes meios de cultivo semi-sólidos. Os isolados foram caracterizados pelo sequenciamento do gene $16 \mathrm{~S}$ rRNA. As características de promoçáo do crescimento vegetal foram avaliadas através da presença do gene nifH, solubilizaçáo de fosfato de alumínio e produção de compostos indólicos. Os isolados foram afiliados a 18 gêneros, pertencentes a cinco diferentes classes ( $\alpha$-Proteobacteria, $\beta$-Proteobacteria, $\gamma$-Proteobacteria, Bacilli e Actinobacteria). O gênero Bacillus foi predominante, principalmente nas áreas de floresta e monocultura. Quatorze isolados apresentaram o gene nifH. A maioria dos isolados foi capaz de solubilizar fosfato de alumínio e sintetizar compostos indólicos. Os resultados indicam uma elevada diversidade de bactérias endofíticas presente em raízes de castanha-do-Brasil, principalmente em área de agrofloresta, que pode estar relacionado aos atributos do solo. Entre os 90 isolados, 22 apresentaram os melhores resultados relacionados às características de promoçáo do crescimento vegetal, e são bons candidatos para testes em produçáo de mudas de castanha-do-Brasil.

PALAVRAS-CHAVE: 16S rRNA, solubilização de fosfatos, compostos indólicos, fixação biológica de nitrogênio, bactéria promotora do crescimento vegetal, Amazônia

CITE AS: Chalita, P.B.; Farias, E. do N.C.; Costa, I.B. da; Sousa, B.F.; Santos, M.A.O. dos; Albuquerque, T.C.S. de; Vital, M.J.S.; Silva, K. da. 2019. Characterization of bacterial endophytes from the roots of native and cultivated Brazil nut trees (Bertholletia excelsa). Acta Amazonica 49 : $257-267$. 


\section{INTRODUCTION}

Brazil nut (Bertholletia excelsa H.B.K.) is native to Brazil, Bolivia, Venezuela, Colombia, Peru and the Guianas (Mori 1992; Lorenzi 2002) and represents the most important commercial nontimber forest product in the Amazon region. Brazil nut trees are long-living organisms, and large trees have been carbon dated with ages of more than 300 years (Vieira et al. 2005). As the nuts are solely harvested in the wild, the sustainable exploitation of Brazil nut contributes to promote Amazonian forest conservation and has enjoyed widespread and longstanding economic success in the international market (Wadt et al. 2008). However, the species also suffers from increasing habitat loss due to deforestation for illegal timber trade, opening of pasture areas, and forest fires. Studies on the introduction of cultivated Brazil nut trees are needed (Camargo et al. 2010), as habitat loss puts the species at risk due to loss of pollinators and seed-dispersing agents, and increased pollination distances (Ortiz 2002). A problem with Brazil nut cultivation is the time required for seed germination (20-60 days) and the uneven time germination of its seeds (Müller et al. 1995).

An alternative for improving the production of Brazil nut seedlings could be the use of plant growth-promoting bacteria (PGPB). These bacteria are able to improve the growth of plants and protect them from disease and abiotic stress (Glick 2012; Souza et al. 2015). PGPB can be found in the rhizosphere, on the root surfaces, or in the internal tissues of plants. PGPB that colonize internal tissues are known as endophytes and are found in nearly every plant worldwide (Santoyo et al. 2016) and do not harm the plant (Hallman et al. 1997). Endophytic bacteria can accelerate seedling emergence and increase plant growth (Chanway 1997). The mechanisms involved in plant growth promotion by these bacteria are similar to those observed among rhizobacteria, such as nitrogen fixation, phytohormone production, phosphate solubilization, and the production of antifungal compounds, induction of systemic resistance and production of siderophores (Vessey 2003; Compant et al. 2010; Glick 2012; Chanway 1997), which are bioactive compounds produced by bacteria that are readily available to the plant (Afzal et al. 2019). To date, there is no information about the isolation or characterization of endophytic PGPB from Brazil nut trees. The isolation and characterization of endophytic plant growth-promoting bacteria from Brazil nut roots would be important for the identification of new biological inoculants which may provide an alternative approach for the improvement of seed germination and seedling development.

Bacterial diversity in Amazon soils is higher in association with more intensive land uses than in undisturbed primary forest (Carvalho et al. 2016). Land use and changes in soil fertility, especially $\mathrm{pH}$, alter the bacterial community composition (Jesus et al. 2009, Carvalho et al. 2016). Therefore, the main hypothesis of our study was that cultivated Brazil nut trees may harbor a greater diversity of endophytic bacteria than those in native forest areas. An additional hypothesis was that endophytic bacteria associated with Brazil nut roots exhibit mechanisms for promoting plant growth, such as the ability to solubilize phosphates and produce phytohormones. To test these hypotheses, we isolated and characterized endophytic bacteria from Brazil nut trees in an area of native terra firme forest and two experimental cultivation areas in the state of Roraima (northern Brazilian Amazon region), one containing only a monoculture of Brazil nut trees, and an agroforestry system containing Brazil nut trees in combination with other agricultural activities. The isolates were then tested to identify the mechanisms of plant growth promotion.

\section{MATERIAL AND METHODS}

\section{Origin of bacteria}

Root samples were collected between April and October 2013 in three areas in Roraima State, Brazil (Figure 1): (a) from 11 trees in a monoculture of Brazil nut trees planted in 2007 in the Serra da Prata experimental field of Embrapa Roraima in the city of Mucajaí (02²2'28.2”N, 6059'46.8”W) [the Brazil nut seedlings received $100 \mathrm{~g}$ of triple superphosphate at the tips at planting, and, after two years, $30 \mathrm{~kg} \mathrm{ha}^{-1}$ of $\mathrm{N}$ (ammonium sulfate) and $30 \mathrm{~kg} \mathrm{ha}^{-1}$ of $\mathrm{K}_{2} \mathrm{O}$ (potassium chloride) in the crown projection area]; (b) from 10 trees in an agroforestry system planted in 1995 in the Confiança experimental field of Embrapa Roraima, in the city of Cantá $\left(02^{\circ} 15^{\prime} 00^{\prime} \mathrm{N}\right.$, $60^{\circ} 39^{\prime} 54^{\prime \prime W}$ ) [the area was plowed and received $2000 \mathrm{~kg} \mathrm{ha}^{-1}$ liming (PRNT 100\%), $40 \mathrm{~kg} \mathrm{ha}^{-1} \mathrm{P}_{2} \mathrm{O}_{5}$ and $50 \mathrm{~kg} \mathrm{ha}^{-1}$ of FTE BR12 Nutriplant (7.1\% Ca, 5.7\% S, 1.8\% B, 0.8\% Cu, 2.0\% $\mathrm{Mn}, 0.1 \% \mathrm{Mo}$, and $9.0 \% \mathrm{Zn}$ ) as a source of micronutrients]. Apart from Brazil nut, other species planted were cupiúba (Goupia glabra Aubl.), peach palm (Bactris gasipaes Kunth.), cupuassu (Theobroma grandiflorum Schum.), coffee (Coffea canephora Pierre.), rain tree (Samanea saman (Jacq.) Merr.) and andiroba (Carapa guianensis Aubl.)]; and (c) from seven trees in a dense ombrophilous forest in a private estate located in Sáo João da Baliza (057’024”N, 5954’41”W).

The climate in the region of the monoculture and agroforestry areas is Ami (Köppen system), with mean annual temperatures ranging from 26 to $29{ }^{\circ} \mathrm{C}$, and rainfall from around 1800 to 2400 (Oliveira Junior et al. 2003), and the soil type is a red-yellow ultisol, representing an area of savannaforest transition on a flat relief. In the forest area the relief is flat to wavy, with climate of type Awi (Köppen system), with mean annual temperature of $27^{\circ} \mathrm{C}$ and rainfall range from 1700 to $2000 \mathrm{~mm}$; the soils were not classified, but yellow ultisols and oxisols are predominant in the region (Femact 1993; Seplan 2010). Soil samples from the three sampling areas were chemically and physically characterized by Embrapa (1997) (parameters are presented in Table 1). 


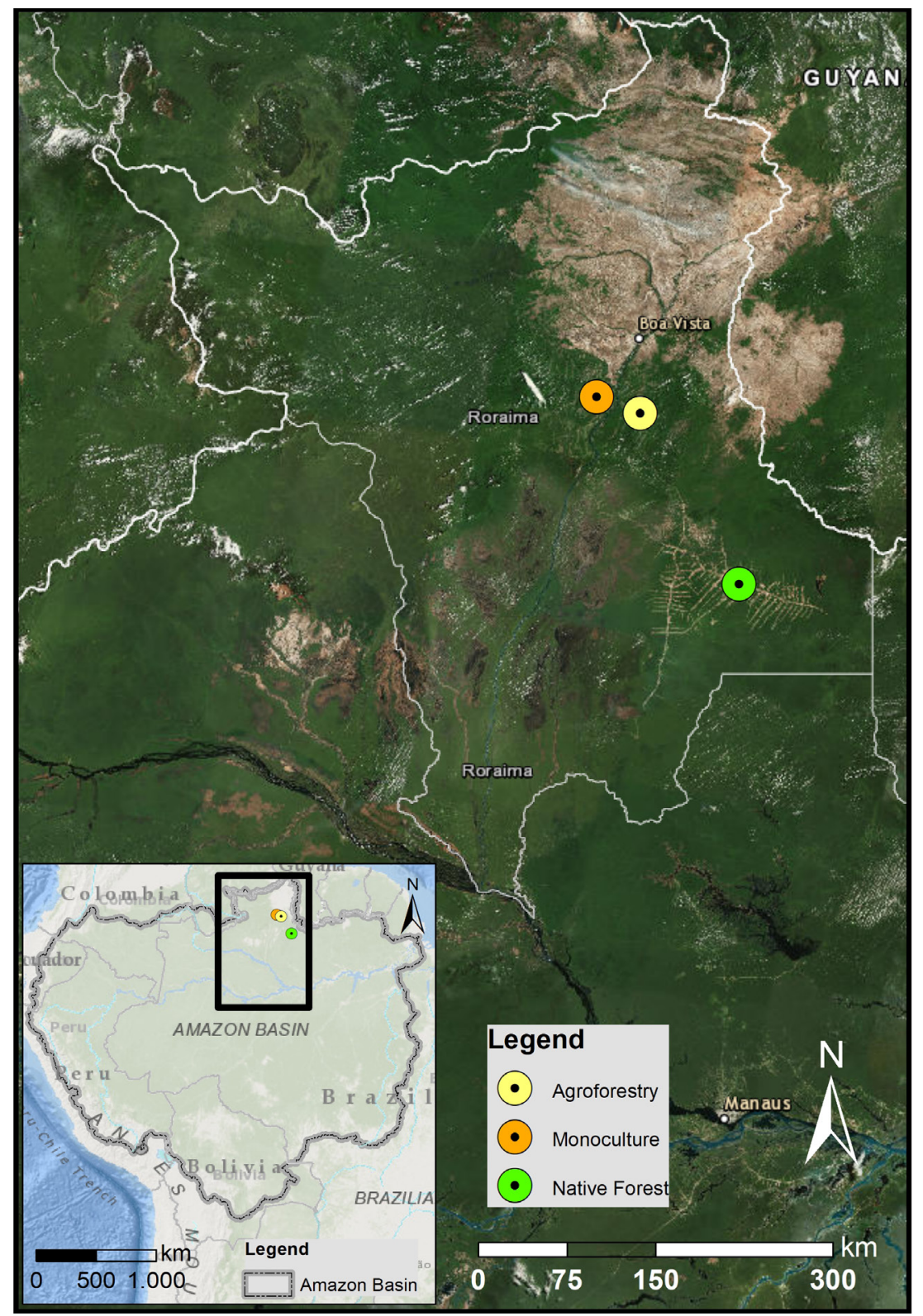

Figure 1. Location of the three sampling areas for bacterial isolates from roots of Brazil nut (Bertholletia excelsa) trees in the state of Roraima, in the northern Brazilian Amazon. This figure is in color in the electronic version.

Bacteria were isolated from nonwoody roots in different semisolid culture media that included NFb, LGI (both of which favor the growth of Azospirillum spp.) (Döbereiner $e t$ al. 1995), JMV (Burkholderia spp.) (Estrada De Los Santos et al. 2001) and DYG's (nonselective) (Rodrigues Neto et al. 1986). The roots were washed with water and cut into fragments of approximately $1 \mathrm{~cm}$ in length. then subjected to surface disinfection with sodium hypochlorite $(2 \%)$ for $2 \mathrm{~min}$ and then hydrogen peroxide (5\%) for $1 \mathrm{~min}$, after which they were washed six times with sterilized water. The media with roots (5 replicates) were incubated for 10 days in a growth chamber at $28^{\circ} \mathrm{C}$. The isolation was performed from all the cultures that presented growth, i.e., the formation of a pellicle in the medium. After confirmation of bacterial growth, a loopful of the pellicle was streaked onto the corresponding solid medium to isolate the bacterium based on the phenotypic characteristics of the colonies (Döbereiner $e t$ al. 1995). After isolation, the following colony characteristics were evaluated: growth time, average diameter, shape, margin, surface, elevation, color and gum production. Ninety bacteria were selected from 303 obtained isolates ( 41 isolates from the agroforestry system, 30 from the monoculture system and, 19 from the native terra firme forest). All isolates obtained were stored at $-80^{\circ} \mathrm{C}$ in $20 \%$ glycerol. 
Table 1. Chemical and physical attributes of the soil in areas where roots of Brazil nut (Bertholletia excelsa) trees were sampled in Roraima state (northern Brazil). Data from Embrapa (1997).

\begin{tabular}{|c|c|c|c|c|}
\hline Areas & Measure unit & Agroforestry & Monoculture & $\begin{array}{c}\text { Native terra firme } \\
\text { Forest }\end{array}$ \\
\hline \multicolumn{5}{|c|}{ Chemical attributes } \\
\hline $\mathrm{pH}$ (water) & & 5.9 & 4.8 & 4.5 \\
\hline $\mathrm{Ca}^{2+}$ & $\mathrm{cmol}_{c} \mathrm{dm}^{-3}$ & 3.5 & 1.2 & 0.33 \\
\hline $\mathrm{Mg}^{2+}$ & $\mathrm{Cmol}_{c} \mathrm{dm}^{-3}$ & 0.7 & 0.4 & 0.19 \\
\hline $\mathrm{K}^{+}$ & $\mathrm{cmol}_{\mathrm{c}} \mathrm{dm}^{-3}$ & 0.2 & 0.04 & 0.19 \\
\hline $\mathrm{Al}^{3+}$ & $\mathrm{cmol}_{\mathrm{c}} \mathrm{dm}^{-3}$ & 0.1 & 1 & 0.82 \\
\hline $\mathrm{H}+\mathrm{Al}$ & $\mathrm{cmol}_{c} \mathrm{dm}^{-3}$ & 5.12 & 2.3 & 5.77 \\
\hline $\mathrm{P}$ & $m g \mathrm{dm}^{-3}$ & 19.33 & 3 & 1.95 \\
\hline V & $\%$ & 44.9 & 41 & 11 \\
\hline O.M. & $\mathrm{g} \mathrm{dm}^{-3}$ & 41.4 & 7 & 23 \\
\hline \multicolumn{5}{|c|}{ Physical attributes } \\
\hline Argila & $\%$ & 23 & 28 & 28 \\
\hline Silte & $\%$ & 8 & 15 & 15 \\
\hline Areia & $\%$ & 69 & 57 & 57 \\
\hline
\end{tabular}

$\mathrm{V}$ (base saturation), O. M (organic matter)

\section{S rRNA partial sequencing}

Bacteria were grown in DYG's liquid medium (Rodrigues Neto et al. 1986) for $24 \mathrm{~h}$, after which their DNA was extracted from $1 \mathrm{ml}$ of cell suspension with an RBC extraction kit (cat. YGB300, Taiwan), following the instructions provided by the manufacturer. Amplification of the $16 \mathrm{~S}$ rRNA gene was performed using the 27F (5'-AGAGTTTGATCCTGGCTCAG-3') and 1492R (5'-GGTTACCTTGTTACGACTT-3') primers (Lane 1991), and partial sequencing was performed using the $27 \mathrm{~F}$ primer. Sequencing was performed using a 3730xl DNA sequencer (Applied Biosystems, Foster City, CA, USA). The sequences were aligned using the ClustalW program (Thompson et al. 1994) in MEGA 5.01 software (Tamura et al. 2011). A phylogenetic tree was constructed using the "neighbor-joining" method and Kimura's 2-parameter model (Kimura 1980) with MEGA 5.01 software, performing 1000 repetitions. The $16 \mathrm{~S}$ rRNA gene sequences were deposited in the GenBank database under accession numbers MF442264MF442353.

\section{nifH gene amplification}

The nifH gene was amplified using the primers $19 \mathrm{~F}$ (5'-CCI WTYTAYGGIAARGGIGG-3') and 407R (5'-AAICCRCCRCAIACIACRTC-3') (Ueda et al. 1995).

\section{Aluminum phosphate solubilization assays}

An initial qualitative estimation of the P-solubilizing activity of the bacteria was carried out on modified National Botanical Research Institute Phosphorus (NBRIP) agar (Nautiyal 1999). Tricalcium phosphate was substituted with aluminum phosphate $\left(\mathrm{AlPO}_{4}, 0.236 \%\right)$, and the $\mathrm{pH}$ of the medium was adjusted to 4.5. All isolates were cultured in DYG'S liquid medium for $24 \mathrm{~h}$ at $28^{\circ} \mathrm{C}$ until the cell concentration measured via the optical density at $630 \mathrm{~nm}\left(\mathrm{OD}_{630}\right)$ reached 0.5-0.7. Ten-microliter samples of the bacterial cultures were inoculated into NBPRIP medium at three equidistant points on a plate, which was subsequently incubated for 18 days at $28^{\circ} \mathrm{C}$.

A quantitative assay was also performed using NBPRIP liquid medium. One milligram of cells from the isolates cultured in DYG'S solid medium was inoculated into 30 $\mathrm{mL}$ of NBPRIP with $\mathrm{AlPO}_{4}$ at a concentration of $12 \mathrm{mg} \mathrm{P}$ $1^{-1}$. These cultures were incubated at $28^{\circ} \mathrm{C}$ for 4 days under $150 \mathrm{rpm}$ agitation. At the end of this period, the $\mathrm{pH}$ was determined; each sample was centrifuged (10 $000 \mathrm{rpm}$ for $5 \mathrm{~min}$ ), and the levels of soluble $\mathrm{P}$ in the supernatant were quantified using the phosphomolybdate method (Murphy and Riley 1962). The concentration of $P$ was estimated using a standard curve previously prepared with $0,0.1,0.5,0.75,1$, 2, 3, 4, 4.5, 5 and $6 \mathrm{mg} \mathrm{l}^{-1} \mathrm{P}$ in the form of $\mathrm{KH}_{2} \mathrm{PO}_{4}$.

In all tests, BR $11001^{\mathrm{T}}$ (Azospirillum brasiliense), BR 11340 (Burkholderia sp.), BR11175 ${ }^{\mathrm{T}}$ (Herbaspirillum seropedicae), BR $11790^{\mathrm{T}}$ (Herbaspirillum frisigense), and ERR 532 (Bacillus sp. isolated from the roots of Brachiaria sp.) were included for comparison. The experiments were completely randomized with three replications. The data were statistically analyzed using the SISVAR program, version 4.3 (Ferreira 2011), with the effects from the treatments evaluated by the Scott-Knott test (Scott and Knott 1974) at a 5\% level of significance.

\section{Production of indole compounds}

The isolates and the type and reference strains, as well as Azospirillum brasilense BR $11001^{\mathrm{T}}$ (Radwan et al. 2002), Herbaspirillum seropedicae BR $11175^{\mathrm{T}}$ (Baldani et al. 1986), Burkholderia sp. BR11340, Herbaspirillum frisigense BR11790', and ERR 532 (Bacillus sp. isolate from roots of Brachiaria sp.), were cultured in DYG'S liquid medium (Rodrigues Neto et al. 1986) for $24 \mathrm{~h}$. After growth, the cultures were adjusted to an $\mathrm{OD}_{630}$ ranging from $0.6-0.8$. Then, $500 \mu \mathrm{l}$ aliquots of the bacterial cultures were inoculated into $6 \mathrm{ml}$ of DYG's medium (without $\mathrm{L}_{\mathrm{L}}$-tryptophan or supplemented with 100

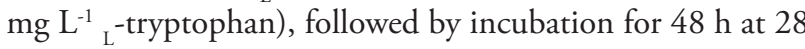
${ }^{\circ} \mathrm{C}$ under constant stirring at $150 \mathrm{rpm}$. The cultures were recovered after centrifugation at $10.000 \mathrm{rpm}$ g for $5 \mathrm{~min}$, and $3 \mathrm{ml}$ of the recovered supernatant and $2 \mathrm{ml}$ of Salkowski reagent were then mixed together (Sarwar and Kremer 1995). This mixture was incubated in the dark for $20 \mathrm{~min}$, until a pink color developed that is indicative of indole production. The color intensity was measured in a spectrophotometer at $535 \mathrm{~nm}$. The concentration of indoles was estimated using a standard curve prepared with $0,10,25,50,75$ and 100 $\mu \mathrm{g}$ AIA ml ${ }^{-1}$ (Sigma-Aldrich, cod. I3750). The experiments were completely randomized with three replications. The data 
were then statistically analyzed as described for the phosphate solubilization assays.

\section{Selection of bacteria}

For the selection of bacteria exhibiting growth-promoting characteristics, histograms were constructed to visualize the data and group the isolates (data not shown). Bacteria associated with relatively higher phosphate solubilization and indole compound production were selected.

\section{RESULTS}

\section{S rRNA partial sequencing}

The closest matches for the 90 bacterial isolates within the NCBI database are presented in Table 2. The 90 endophytic bacteria were affiliated with 18 genera belonging to 5 different classes: $\alpha$-Proteobacteria, $\beta$-Proteobacteria, $\gamma$-Proteobacteria, Bacilli and Actinobacteria. Members of the classes Bacilli $(43.3 \%)$ and $\gamma$-Proteobacteria $(32.2 \%)$ were predominant followed by $\beta$-Proteobacteria (12.2\%), $\alpha$-Proteobacteria (6.7\%) and Actinobacteria (5.6\%). In the class Bacilli, the genus Bacillus was predominant, with 30 isolates. Stenotrophomonas (10 isolates) was predominant in the class $\gamma$-Proteobacteria, and Burkholderia and Achromobacter, both with four isolates, in the class $\beta$-Proteobacteria. Members of the predominantly occurring genus Bacillus were obtained mainly from the native-forest and monoculture samples. The greatest diversity of bacterial genera was isolated from the agroforestry samples.

\section{nifH gene amplification}

Fourteen bacterial isolates were positive for the amplification of DNA with primers $19 \mathrm{~F}$ and $407 \mathrm{R}$, corresponding to a region of the nifH gene (approximately $400 \mathrm{bp}$ ). These bacteria were identified as belonging to Bacillus (ERR 667, ERR 679, ERR 785, ERR 819, ERR 821 and ERR 830), Paenibacillus (ERR 684), Enterobacter (ERR 604 and ERR 838), Klebsiella (ERR 602), Stenotrophomonas (ERR 640), Pseudomonas (ERR 711), Delftia (ERR 762) and Microbacterium (ERR 773) (Table 2). Seven of these isolates were from the agroforestry system; four from the forest, and three from the monoculture. Among the 14 isolates, five were obtained from media selective for Azospirillum spp. (NFb and LGI) (ERR 602, ERR 604, ERR 640, ERR 830, ERR 838) and nine from nonselective medium (DYG's medium) (ERR 667, ERR 679, ERR 684, ERR 711, ERR 762, ERR 773, ERR 785, ERR 819, ERR 821).

\section{Aluminum phosphate solubilization assays}

None of the bacteria or type strains showed a halo of solubilization on solid medium. In liquid medium, however, $88.9 \%$ of the isolates were able to solubilize aluminum phosphate (Table 3). Some isolates, such as ERR 587, ERR 589, ERR 733, ERR 719 and ERR 584, had significantly higher values and made available up to $14 \%$ of the $\mathrm{P}$ added to the medium (Table 3).
Table 2. Identification of 90 bacterial isolates sampled from roots of Brazil nut (Bertholletia excelsa) trees in native and cultivated habitats in Roraima (northern Brazil). The closest match in the NCBI database of the partial sequencing of the $16 \mathrm{~S}$ rRNA gene is indicated, as well as the origin and medium of isolation of the isolates

\begin{tabular}{|c|c|c|c|}
\hline Isolates & Closest match & Origin & Medium \\
\hline \multicolumn{4}{|c|}{ Class a -Proteobacteria } \\
\hline ERR 739 & Ochrobactrum & Agroforestry & DYG'S \\
\hline ERR 745 & Ochrobactrum & Agroforestry & DYG'S \\
\hline ERR 792 & Ochrobactrum & Forest & DYG'S \\
\hline ERR 858 & Agrobacterium/Rhizobium & Agroforestry & $\mathrm{NFb}$ \\
\hline ERR 865 & Agrobacterium/Rhizobium & Agroforestry & $\mathrm{NFb}$ \\
\hline ERR 870 & Agrobacterium/Rhizobium & Agroforestry & $\mathrm{NFb}$ \\
\hline \multicolumn{4}{|c|}{ Class $\beta$ - Proteobacteria } \\
\hline ERR 584 & Burkholderia & Agroforestry & JMV \\
\hline ERR 587 & Burkholderia & Forest & JMV \\
\hline ERR 589 & Burkholderia & Monoculture & JMV \\
\hline ERR 594 & Burkholderia & Monoculture & JMV \\
\hline ERR 689 & Achromobacter/Uncultured & Monoculture & DYG'S \\
\hline ERR 737 & Achromobacter/Uncultured & Agroforestry & DYG'S \\
\hline ERR 738 & Achromobacter & Agroforestry & DYG'S \\
\hline ERR 744 & Uncultured & Agroforestry & DYG'S \\
\hline ERR 763 & Achromobacter/ Uncultured & Agroforestry & DYG'S \\
\hline ERR 772 & Delftia & Agroforestry & DYG'S \\
\hline ERR 762 & Delftia & Agroforestry & DYG'S \\
\hline \multicolumn{4}{|c|}{ Class $\gamma$ - Proteobacteria } \\
\hline ERR 596 & Pantoea & Monoculture & LGI \\
\hline ERR 602 & Klebsiella & Agroforestry & LGl \\
\hline ERR 604 & Enterobacter & Agroforestry & LGl \\
\hline ERR 626 & Klebsiella & Agroforestry & LGl \\
\hline ERR 640 & Stenotrophomonas & Agroforestry & LGl \\
\hline ERR 652 & Enterobacter & Monoculture & DYG'S \\
\hline ERR 692 & Enterobacter & Monoculture & DYG'S \\
\hline ERR 710 & Pseudomonas & Agroforestry & DYG'S \\
\hline ERR 711 & Pseudomonas & Agroforestry & DYG'S \\
\hline ERR 719 & Serratia & Agroforestry & DYG'S \\
\hline ERR 720 & Pseudomonas & Agroforestry & DYG'S \\
\hline ERR 721 & Pseudomonas & Agroforestry & DYG'S \\
\hline ERR 723 & Pseudomonas & Agroforestry & DYG'S \\
\hline ERR 727 & Enterobacter & Agroforestry & DYG'S \\
\hline ERR 750 & Uncultured & Agroforestry & DYG'S \\
\hline ERR 752 & Pseudomonas & Agroforestry & DYG'S \\
\hline ERR 761 & Uncultured/Stenotrophomonas & Agroforestry & DYG'S \\
\hline ERR 765 & Pseudomonas & Agroforestry & DYG'S \\
\hline ERR 770 & Stenotrophomonas/Uncultured & Agroforestry & DYG'S \\
\hline ERR 771 & Stenotrophomonas & Agroforestry & DYG'S \\
\hline ERR 779 & Pseudomonas & Forest & DYG'S \\
\hline ERR 782 & Uncultured & Forest & DYG'S \\
\hline ERR 828 & Stenotrophomonas & Agroforestry & $\mathrm{NFb}$ \\
\hline ERR 833 & Enterobacter & Forest & $\mathrm{NFb}$ \\
\hline ERR 838 & Uncultured & Agroforestry & $\mathrm{NFb}$ \\
\hline ERR 843 & Stenotrophomonas/Uncultured & Agroforestry & $\mathrm{NFb}$ \\
\hline ERR 849 & Uncultured & Agroforestry & $\mathrm{NFb}$ \\
\hline ERR 859 & Stenotrophomonas & Agroforestry & $\mathrm{NFb}$ \\
\hline ERR 873 & Uncultured & Agroforestry & $\mathrm{NFb}$ \\
\hline
\end{tabular}


Table 2. Continued.

\begin{tabular}{|c|c|c|c|}
\hline Isolates & Closest match & Origin & Medium \\
\hline \multicolumn{4}{|c|}{ Class Bacilli } \\
\hline ERR 575 & Paenibacillus & Agroforestry & JMV \\
\hline ERR 651 & Bacillus & Monoculture & DYG'S \\
\hline ERR 654 & Bacillus & Monocuture & DYG'S \\
\hline ERR 656 & Lysinibacillus & Monoculture & DYG'S \\
\hline ERR 657 & Bacillus & Monoculture & DYG'S \\
\hline ERR 660 & Bacillus & Monoculture & DYG'S \\
\hline ERR 665 & Bacillus & Monoculture & DYG'S \\
\hline ERR 667 & Bacillus & Monoculture & DYG'S \\
\hline ERR 673 & Bacillus & Monoculture & DYG'S \\
\hline ERR 676 & Bacillus & Monoculture & DYG'S \\
\hline ERR 677 & Paenibacillus & Monoculture & DYG'S \\
\hline ERR 678 & Paenibacillus & Monoculture & DYG'S \\
\hline ERR 679 & Bacillus & Monoculture & DYG'S \\
\hline ERR 680 & Bacillus & Monoculture & DYG'S \\
\hline ERR 684 & Paenibacillus & Monoculture & DYG'S \\
\hline ERR 691 & Bacillus & Monoculture & DYG'S \\
\hline ERR 694 & Bacillus & Monoculture & DYG'S \\
\hline ERR 701 & Bacillus & Monoculture & DYG'S \\
\hline ERR 703 & Lysimibacillus & Monoculture & DYG'S \\
\hline ERR 705 & Bacillus & Monoculture & DYG'S \\
\hline ERR 706 & Bacillus & Monoculture & DYG'S \\
\hline ERR 708 & Bacillus & Monoculture & DYG'S \\
\hline ERR 709 & Bacillus & Monoculture & DYG'S \\
\hline ERR 717 & Lysinibacillus & Agroforestry & DYG'S \\
\hline ERR 741 & Bacillus & Agroforestry & DYG'S \\
\hline ERR 785 & Bacillus & Forest & DYG'S \\
\hline ERR 794 & Lysinibacillus & Forest & DYG'S \\
\hline ERR 795 & Bacillus & Forest & DYG'S \\
\hline ERR 797 & Bacillus & Forest & DYG'S \\
\hline ERR 799 & Bacillus & Forest & DYG'S \\
\hline ERR 800 & Paenibacillus & Forest & DYG'S \\
\hline ERR 803 & Bacillus cereus & Forest & DYG'S \\
\hline ERR 805 & Bacillus & Forest & DYG'S \\
\hline ERR 807 & Bacillus & Forest & DYG'S \\
\hline ERR 809 & Bacillus & Forest & DYG'S \\
\hline ERR 813 & Bacillus & Forest & DYG'S \\
\hline ERR 819 & Bacillus & Forest & DYG'S \\
\hline ERR 821 & Bacillus & Forest & DYG'S \\
\hline ERR 830 & Bacillus & Forest & $\mathrm{NFb}$ \\
\hline \multicolumn{4}{|c|}{ Class Actinobacteria } \\
\hline ERR 644 & Curtobacterium & Forest & LGl \\
\hline ERR 733 & Microbacterium & Agroforestry & DYG'S \\
\hline ERR 753 & Microbacterium & Agroforestry & DYG'S \\
\hline ERR 773 & Microbacterium & Agroforestry & DYG'S \\
\hline ERR 822 & Curtobacterium & Forest & DYG'S \\
\hline
\end{tabular}

Table 3. Soluble phosphate after solubilization by bacterial isolates sampled from roots of Brazil nut (Bertholletia excelsa) trees in native and cultivated habitats in Roraima (northern Brazil), and reference strains in liquid media. Different letters in columns indicate statistical differences $(p<0.05)$ according to the Skott-Knott test. The coefficient of variation was $35.9 \%$. Isolates in bold were used as controls.

\begin{tabular}{|c|c|c|c|c|c|c|c|}
\hline Isolate & $\begin{array}{c}\text { Soluble P } \\
\left(\mathrm{mg} \mathrm{l}^{-1}\right)\end{array}$ & $\mathrm{pH}$ & $\begin{array}{c}\text { Soluble P } \\
(\%)\end{array}$ & Isolate & $\begin{array}{c}\text { Soluble P } \\
\left(\mathrm{mgl}^{-1}\right)\end{array}$ & $\mathrm{pH}$ & $\begin{array}{c}\text { Soluble P } \\
(\%)\end{array}$ \\
\hline ERR 587 & $1.69 \mathrm{a}$ & 3.7 & 14.1 & ERR 805 & $0.30 \mathrm{e}$ & 3.7 & 2.5 \\
\hline ERR 589 & $1.54 \mathrm{a}$ & 3.0 & 12.8 & ERR 677 & $0.25 \mathrm{e}$ & 3.9 & 2.1 \\
\hline ERR 733 & $1.38 \mathrm{a}$ & 3.0 & 11.5 & ERR 828 & $0.24 \mathrm{e}$ & 4.4 & 2.0 \\
\hline ERR 719 & $1.23 \mathrm{~b}$ & 3.1 & 10.2 & ERR 640 & $0.24 \mathrm{e}$ & 3.8 & 2.0 \\
\hline ERR 584 & $1.14 b$ & 3.3 & 9.5 & ERR 779 & $0.23 \mathrm{e}$ & 4.0 & 1.9 \\
\hline ERR 723 & $0.99 c$ & 3.3 & 8.3 & ERR 799 & $0.23 \mathrm{e}$ & 4.4 & 1.9 \\
\hline ERR 833 & $0.98 c$ & 3.4 & 8.1 & ERR 809 & $0.22 \mathrm{e}$ & 4.7 & 1.9 \\
\hline ERR 727 & $0.96 c$ & 3.4 & 8.0 & ERR 813 & $0.22 \mathrm{e}$ & 4.4 & 1.9 \\
\hline ERR 773 & $0.93 c$ & 4.1 & 7.8 & ERR 738 & $0.22 \mathrm{e}$ & 4.7 & 1.8 \\
\hline ERR 753 & $0.84 c$ & 4.2 & 7.0 & ERR 800 & $0.20 \mathrm{f}$ & 4.1 & 1.7 \\
\hline ERR 765 & $0.83 c$ & 4.1 & 6.9 & ERR 706 & $0.20 \mathrm{f}$ & 4.3 & 1.6 \\
\hline ERR 721 & $0.78 c$ & 4.1 & 6.5 & ERR 772 & $0.20 \mathrm{f}$ & 4.2 & 1.6 \\
\hline ERR 694 & $0.78 c$ & 3.9 & 6.5 & ERR 858 & $0.20 \mathrm{f}$ & 4.3 & 1.6 \\
\hline ERR 752 & $0.76 \mathrm{c}$ & 4.0 & 6.3 & BR 11001 & $0.19 f$ & 3.8 & 1.6 \\
\hline ERR 678 & $0.72 \mathrm{~d}$ & 4.0 & 6.0 & ERR 657 & $0.19 f$ & 3.5 & 1.6 \\
\hline ERR 594 & $0.72 d$ & 3.4 & 6.0 & ERR 744 & $0.19 f$ & 4.0 & 1.6 \\
\hline ERR 602 & $0.69 d$ & 3.3 & 5.8 & ERR 692 & & 3.4 & 1.3 \\
\hline ERR 821 & $0.69 d$ & 3.7 & 5.8 & ERR 830 & $0.15 f$ & 4.2 & 1.3 \\
\hline ERR 708 & $0.68 d$ & 3.6 & 5.7 & ERR 575 & $0.14 \mathrm{f}$ & 3.7 & 1.2 \\
\hline BR 11340 & $0.63 d$ & 3.6 & 5.3 & ERR 673 & & 3.0 & 1.2 \\
\hline ERR 604 & $0.62 d$ & 3.9 & 5.2 & ERR 782 & $0.14 \mathrm{f}$ & 4.5 & 1.1 \\
\hline ERR 596 & $0.61 d$ & 3.4 & 5.1 & ERR 849 & $0.14 \mathrm{f}$ & 4.4 & 1.1 \\
\hline ERR 626 & $0.61 \mathrm{~d}$ & 3.3 & 5.1 & ERR 803 & $0.13 f$ & 4.5 & 1.1 \\
\hline ERR 652 & $0.60 d$ & 3.4 & 5.0 & ERR 865 & $0.13 f$ & 4.4 & 1.1 \\
\hline ERR 711 & $0.58 d$ & 3.9 & 4.8 & ERR 651 & $0.12 \mathrm{f}$ & 4.2 & 1.0 \\
\hline ERR 720 & $0.58 d$ & 4.1 & 4.8 & ERR 870 & $0.12 f$ & 4.6 & 1.0 \\
\hline ERR 838 & $0.58 d$ & 3.5 & 4.8 & ERR 795 & $0.11 \mathrm{f}$ & 4.4 & 0.9 \\
\hline ERR 739 & $057 d$ & 3.8 & 4.8 & ERR 761 & $0.10 \mathrm{f}$ & 4.6 & 0.9 \\
\hline ERR 771 & $0.57 d$ & 3.7 & 4.7 & ERR 656 & $0.10 \mathrm{f}$ & 4.3 & 0.8 \\
\hline ERR 785 & $0.55 d$ & 4.1 & 4.6 & ERR 750 & $0.09 f$ & 4.3 & 0.8 \\
\hline ERR 684 & $0.53 d$ & 3.8 & 4.4 & ERR 807 & $0.09 f$ & 4.5 & 0.8 \\
\hline ERR 667 & $0.52 d$ & 3.6 & 4.3 & ERR 859 & $0.09 f$ & 4.3 & 0.8 \\
\hline ERR 680 & $0.48 \mathrm{e}$ & 3.7 & 4.0 & ERR 770 & $0.09 f$ & 4.5 & 0.7 \\
\hline ERR 745 & 0.45 e & 3.9 & 3.7 & ERR 665 & $0.08 \mathrm{f}$ & 4.2 & 0.7 \\
\hline ERR 763 & $0.45 \mathrm{e}$ & 3.7 & 3.7 & ERR 737 & $0.08 \mathrm{f}$ & 4.4 & 0.7 \\
\hline BR 11790 & $0.44 \mathrm{e}$ & 4.1 & 3.6 & ERR 822 & $0.08 \mathrm{f}$ & 3.9 & 0.7 \\
\hline ERR 532 & $0.42 \mathrm{e}$ & 3.6 & 3.5 & ERR 843 & $0.08 \mathrm{f}$ & 4.2 & 0.7 \\
\hline ERR 741 & $0.40 \mathrm{e}$ & 3.9 & 3.3 & ERR 703 & $0.07 f$ & 4.0 & 0.6 \\
\hline ERR 717 & $0.39 \mathrm{e}$ & 4.4 & 3.2 & ERR 644 & $0.07 f$ & 3.9 & 0.6 \\
\hline ERR 710 & 0.37 e & 4.0 & 3.1 & ERR 660 & $0.06 f$ & 4.2 & 0.5 \\
\hline ERR 762 & 0.37 e & 4.1 & 3.1 & ERR 679 & $0.06 \mathrm{f}$ & 4.3 & 0.5 \\
\hline BR 11175 & $0.36 \mathrm{e}$ & 4.2 & 3.0 & ERR 654 & $0.05 f$ & 4.4 & 0.4 \\
\hline ERR 819 & $0.35 \mathrm{e}$ & 4.3 & 2.9 & ERR 691 & $0.01 \mathrm{f}$ & 4.4 & 0.1 \\
\hline ERR 792 & $0.35 \mathrm{e}$ & 3.9 & 2.9 & ERR 701 & $0.01 \mathrm{f}$ & 4.4 & 0.1 \\
\hline ERR 794 & $0.34 \mathrm{e}$ & 4.2 & 2.8 & ERR 705 & $0.01 \mathrm{f}$ & 4.3 & 0.1 \\
\hline ERR 797 & $0.34 \mathrm{e}$ & 4.5 & 2.8 & ERR 873 & $0.01 \mathrm{f}$ & 4.4 & 0.1 \\
\hline ERR 689 & $0.30 \mathrm{e}$ & 3.9 & 2.5 & ERR 676 & $0.01 \mathrm{f}$ & 4.4 & 0.1 \\
\hline
\end{tabular}


Type or reference strains such as $\mathrm{BR} 11001^{\mathrm{T}}$ (A. brasilense), $\mathrm{BR}$ 11340 (Burkholderia sp.), BR $11790^{\mathrm{T}}$ (H. frisigense), BR $11175^{\mathrm{T}}$ (H. seropedicae) and ERR 532 (Bacillus sp.) could also solubilize aluminum phosphate but showed lower solubilization compared to ERR 587, ERR 589, ERR 733 and ERR 719. These isolates were identified as Burkholderia sp. (ERR 587 and ERR 589), Microbacterium sp. (ERR 733) and Serratia sp. (ERR 719). A reduction in the $\mathrm{pH}$ of the media was observed with increasing solubilization for the majority of the bacteria (Table 3).

\section{Production of indole compounds}

Fifty-eight bacteria were able to synthetize indole compounds in media supplemented with tryptophan (Figure 2a). The production of isolates ERR $596\left(184.47 \mu \mathrm{g} \mathrm{ml}^{-1}\right)$, ERR 626 $\left(104.61 \mu \mathrm{g} \mathrm{ml}^{-1}\right)$, and ERR $723\left(92.43 \mu \mathrm{g} \mathrm{ml}^{-1}\right)$, as well as the type strain H. seropedicae BR $11175^{\mathrm{T}}\left(104.67 \mu \mathrm{g} \mathrm{ml}^{-1}\right)$, was significantly greater than that of the other bacteria and the type strain A. brasilense BR $11001^{\mathrm{T}}$. These bacteria were identified as Pantoea sp. (ERR 596), Klebsiella sp. (ERR 626) and Pseudomonas (ERR 723). However, in the absence of tryptophan, the production decreased from ERR 744 (Achromobacter sp.) with $33.77 \mu \mathrm{g} \mathrm{mL} \mathrm{m}^{-1}$, to ERR 779 (Pseudomonas sp.) (31.61 $\left.\mathrm{g} \mathrm{mL}^{-1}\right)$, ERR 710 (Pseudomonas sp.) $\left(30.96 \mu \mathrm{g} \mathrm{mL} \mathrm{mL}^{-1}\right)$, ERR 656 (Lysinibacillus sp.) (30.81 $\mu \mathrm{g}$ $\left.\mathrm{mL}^{-1}\right)$ and ERR 626 (Klebsiella sp.) (30.24 $\left.\mu \mathrm{g} \mathrm{mL}^{-1}\right)$ (Figure 2b).

\section{Selection of bacteria}

After all analyses, 22 bacterial isolates (Table 4) were selected for best results in growth promotion, and as potential candidates for inoculation during seed germination and seedling production of Brazil nut trees. They belonged to 12 genera (Burkholderia, Pantoea, Enterobacter, Klebsiella, Stenotrophomonas, Lysinibacillus, Bacillus, Pseudomonas, Serratia, Microbacterium, Achromobacter and Delftia) and were obtained from the agroforestry system (10), monoculture (6) and terra firme forest (4).

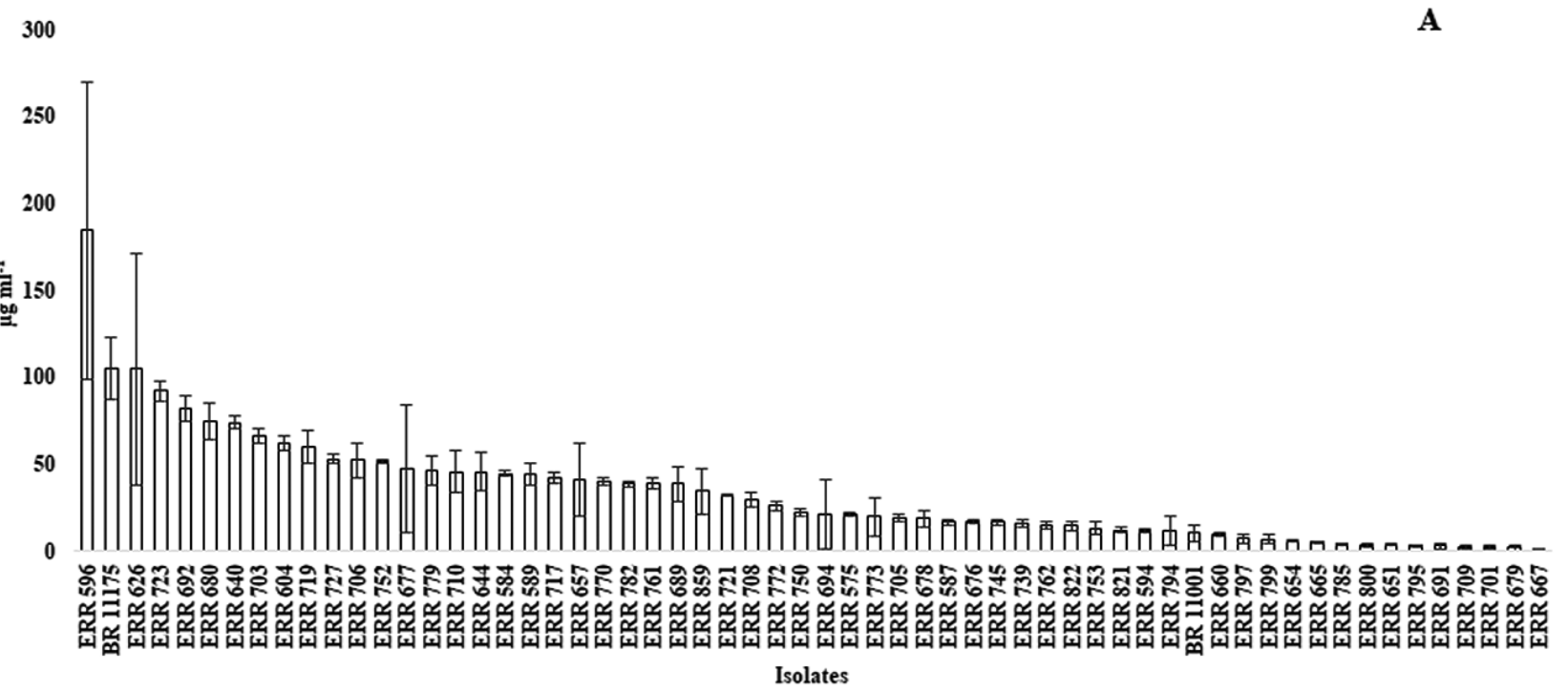

B

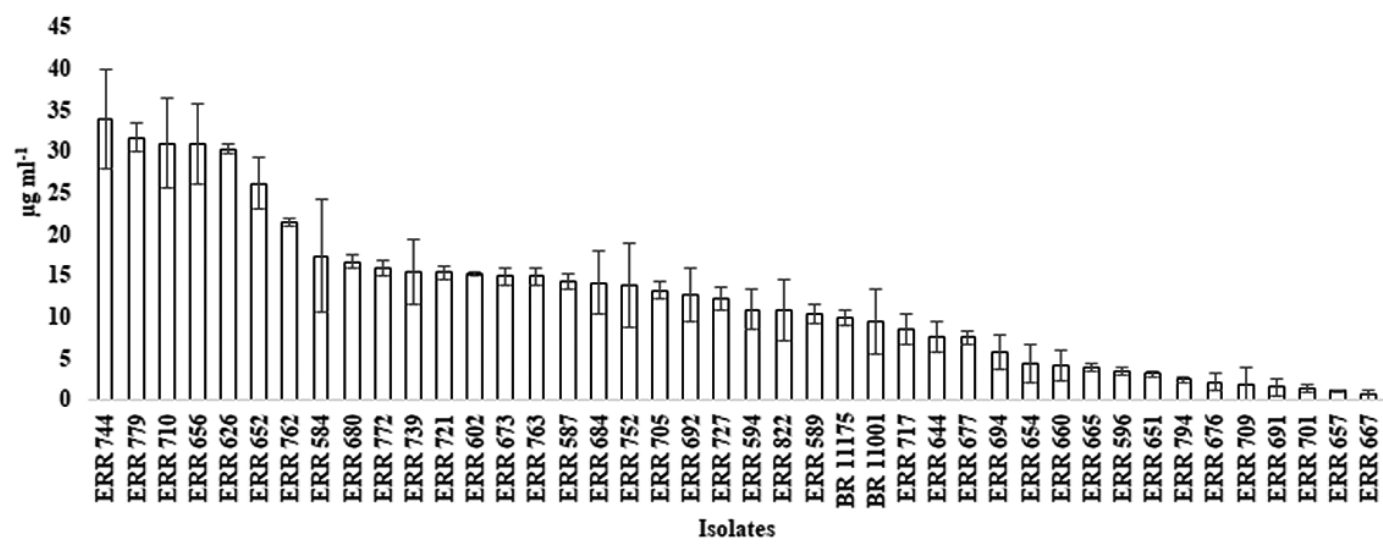

Figure 2. Production of indole compounds by endophytic bacterial isolates obtained from the roots of Brazil nut (Bertholletia excelsa) trees in native and cultivated habitats in media supplemented with (A) and without (B) tryptophan. 
Table 4. Genus, origin and growth promotion characteristics of selected isolates among 90 bacterial isolates sampled from roots of Brazil-nut (Bertholletia excelsa) trees in native and cultivated habitats in Roraima (northern Brazil). *PS = phosphate solubilization; $\mathrm{IC}^{+}=$indole compounds production with tryptophan; $\mathrm{IC}=$ indole compounds production without tryptophan; $\mathrm{NF}=$ nitrogen fixation.

\begin{tabular}{|c|c|c|c|}
\hline Isolate & Genus & Origin & $\begin{array}{l}\text { Growth } \\
\text { promotion* }\end{array}$ \\
\hline ERR 584 & Burkholderia & Agroforestry & PS \\
\hline ERR 587 & Burkholderia & Native Forest & PS \\
\hline ERR 589 & Burkholderia & Monoculture & PS \\
\hline ERR 596 & Pantoea & Monoculture & $\mathrm{IC}^{+}$ \\
\hline ERR 604 & Enterobacter & Agroforestry & $\mathrm{IC}^{+} / \mathrm{NF}$ \\
\hline ERR 626 & Klebsiella & Agroforestry & IC \\
\hline ERR 640 & Stenotrophomonas & Agroforestry & $\mathrm{IC}^{+} / \mathrm{NF}$ \\
\hline ERR 656 & Lysinibacillus & Monoculture & $I^{-}$ \\
\hline ERR 680 & Bacillus & Monoculture & $\mathrm{IC}^{+}$ \\
\hline ERR 692 & Enterobacter & Monoculture & IC \\
\hline ERR 703 & Lysinibacillus & Monoculture & IC \\
\hline ERR 710 & Pseudomonas & Agroforestry & IC \\
\hline ERR 719 & Serratia & Agroforestry & $\mathrm{PS} / \mathrm{IC}^{+}$ \\
\hline ERR 723 & Pseudomonas & Agroforestry & $\mathrm{PS} / \mathrm{IC}^{+}$ \\
\hline ERR 733 & Microbacterium & Agroforestry & PS \\
\hline ERR 744 & Achromobacter & Agroforestry & $\mathrm{IC}^{-}$ \\
\hline ERR 753 & Microbacterium & Agroforestry & PS \\
\hline ERR 773 & Microbacterium & Agroforestry & OS/NF \\
\hline ERR 779 & Pseudomonas & Native Forest & $I^{-}$ \\
\hline ERR 833 & Enterobacter & Native Forest & PS \\
\hline ERR 762 & Delftia & Agroforestry & IC/NF \\
\hline ERR 779 & Pseudomonas & Native Forest & IC \\
\hline
\end{tabular}

\section{DISCUSSION}

We report the first isolation and characterization of endophytic bacteria from the roots of Brazil nut trees. The bacterial classes identified are generally dominated by endophytes in diversity analyses (Santoyo et al. 2016). However, most studies using plant growth-promoting bacteria have been performed with grasses (Moreira et al. 2010), whereas few such works have involved trees. In Brazil, only one study involved endophytic plant growth-promoting bacteria isolated from a native tree species [Araucaria angustifolia (Bertol.) Kuntze.] in southern Brazil (Neroni and Cardoso 2007), which identified diazotrophic bacteria in soil and root samples as belonging to the genus Burkholderia, while the PGPB belonged mainly to Bacillus and Enterobacter. In our Brazil-nut tree root samples, Bacillus was the predominant genus, followed by Stenotrophomonas and Pseudomonas.

The highest diversity of bacterial isolates in our samples was found in the agroforestry system (15 genera), relative to Brazil nut trees in native forest and monoculture (eight and seven genera, respectively). The cultivation of agroforestry systems represents a sustainable practice for carbon sequestration in soil (Abbas et al. 2017). Agroforestry can enrich soil organic carbon, improve soil nutrient availability and fertility due to the presence of trees in the system, litter decomposition and mineralization, and the increase of soil microbial dynamics (Dollinger and Jose 2018). Our agroforestry area also received limestone and fertilizer application, which could be related to an increase in the quantity and quality of litter inputs and, consequently, more soil organic matter accumulation in the soil. In Amazon soils, bacterial community structure and composition are related to land use, likely through the effects of soil attributes, particularly those related to soil acidity (Jesus et al. 2009). These characteristics may explain the higher bacterial diversity associated with Brazil nut roots agroforestry system in our samples, as the soil in this area had lower acidity and higher nutrient content (see Table 1).

The observed diversity was also influenced by the medium utilized for isolation, as the highest diversity was found in DYG'S medium (12 genera), that is rich and nonselective (Rodrigues Neto et al. 1986). For example, the JMV medium is selective for Burkholderia (Estrada De Los Santos et al. 2001), and most isolates obtained from this medium belonged to Burkholderia. We did not detect the presence of Azospirillum spp. using NFb or LGI media, which are known to favor these species (Silva et al. 2011a).

Endophytic bacteria can increase host fitness via many different functions, such as $\mathrm{N}_{2}$ fixation, $\mathrm{P}$ solubilization, and phytohormone production (Compant et al. 2010). Nitrogen fixation has been the focus of many studies seeking alternatives to reduce the use of nitrogen fertilizers (Moreira et al. 2010; Glick 2012). Fourteen of the 90 isolates showed positive amplification of the nifH gene, which qualifies them as potential $\mathrm{N}_{2}$-fixing bacteria that could presumably be considered diazotrophs. The majority were obtained using LGI, NFb and DYG's media and belonged to Klebsiella, Enterobacter, Burkholderia, Stenotrophomonas, Bacillus, Paenibacillus, Pseudomonas, Delftia and Microbacterium.

In acidic soils in tropical regions, most $\mathrm{P}$ is precipitated with iron and aluminum, as is the case in soils from Roraima, which have low natural fertility and contain aluminum (Vale Junior and Leitão Sousa 2005). There are fewer studies involving the solubilization of aluminum phosphate than that of calcium phosphate, but some have reported a halo of solubilization on solid media (Marra et al. 2011, 2012; Oliveira-Longatti et al. 2014), while others have indicated the absence of a halo of solubilization on media with aluminum phosphate (Pérez et al. 2007; Silva et al. 2011a). For our isolates, as well as the type or reference strains tested, no halo of solubilization was observed on the utilized media. Phosphate solubilization tests $(\mathrm{Ca}, \mathrm{Al}$ and $\mathrm{Fe}$ ) have been widely used for the selection of plant growthpromoting bacteria (Hara and Oliveira 2004, 2005; Marra $e t$ al. 2011, 2012; Nautiyal, 1999; Oliveira-Longatti et al. 2014; Silva Filho and Vidor 2000; Silva Filho et al. 2002; Silva et al. 2011b; Silva et al. 2012). However, solubilization tests in solid 
media show relatively poor effectiveness for universal selection to isolate solubilizing bacteria in vitro (Bashan et al. 2012). Bacteria that have performed solubilization many times could grow on solid media without a visible halo and may present other mechanisms of solubilization that do not result in a visible halo (Bashan et al. 2012; Fankem et al. 2008; Illmer et al. 1995). In liquid media, most of our bacterial isolates could solubilize aluminum phosphate, therefore, a visible halo on solid media should not be used as a unique test for solubilizing bacteria, and quantitative tests should also be used (Bashan $e t$ al. 2012). As happened in our samples, Illmer et al. (1995) also reported a $\mathrm{pH}$ reduction in cultures of bacteria and fungi that are able to solubilize aluminum phosphate and attributed the decrease to the production of organic acids and/or $\mathrm{H}^{+}$ excretion accompanying $\mathrm{NH}_{4}$ assimilation. Among the five best phosphorus-solubilizing bacteria in our work, three belong to the Burkholderia genus.

Indole compound production was variable among the isolates, but most of them could produce indoles with and without tryptophan addition. Tryptophan has been identified as a main precursor for IAA biosynthesis pathways in bacteria (Spaepen et al. 2007), which could explain our results regarding greater numbers of bacterial isolates able to produce indolic compounds with tryptophan. The IAA produced by bacteria acts in seed germination and in the radicular system, increasing the size and number of adventitious roots and deep ramifications, allowing a greater volume of soil to be explored by the roots (Glick 2012). This mechanism is an important tool for use in seed germination and seedlings production of Brazil nut.

\section{CONCLUSIONS}

Our results indicated that there is a great diversity of endophytic bacteria in the roots of Brazil nut trees in Roraima state, in the northern Brazilian Amazon. The diversity of genera was higher in isolates obtained from an agroforestry area than in those from a Brazil nut monoculture and a native terra firme forest area. The obtained endophytic bacteria presented plant growth-promotion characteristics, such as nitrogen fixation, phosphate solubilization and indole compound production. Among the 90 isolates obtained, at least 22 that presented the best results for plant-growth promotion traits are promising candidates for use in the seed germination and seedling production of Brazil nut.

\section{REFERENCES}

Abbas, F.; Hammad, H.M.; Fahad, S.; Cerdà, A.; Rizwan, M.; Farhad, W.; Ehsan, S.; Bakhat, H.F. 2017. Agroforestry: a sustainable environmental practice for carbon sequestration under the climate change scenarios - a review. Environmental Science and Pollution Research, 24: 11177-11191.

Afzal, I.; Shinwari, Z.K.; Sikandar, S.; Shahzad, S. 2019. Plant beneficial endophytic bacteria: mechanisms, diversity, host range and genetic determinants. Microbiological Research, 221:36-49.
Baldani, J.I.; Baldani, V.; Seldin, L.; Döbereiner; J. 1986. Characterization of Herbaspirillum seropedicae gen. nov., sp. nov., a root-associated nitrogen-fixing bacterium. International Journal of Systematic Bacteriology, 36: 86-93.

Bashan, Y.; Kamnev, A.A.; De-Bashan, L.E. 2012 Tricalcium phosphate is inappropriate as a universal selection factor for isolating and testing phosphate-solubilizing bacteria that enhance plant growth: a proposal for an alternative procedure. Biology and Fertility of Soils, 49: 465-479.

Camargo, F.F.; Costa, R.B.; Resende, M.D.V.; Roa, R.A.R.; Rodrigues, N.B.; Santos, L.V.; Freitas, C.A. 2010. Genetic variability for morphometric characteristics in Brazilian nut parent trees from northern Mato Grosso, Amazon rain forest. Acta Amazonica, 40: 705-710.

Carvalho, T.S.; Jesus, E.C.; Barlow, J.; Gardner, T.A.; Soares, I.C.; Tiedje, J.M.; Moreira, F.M.S. 2016. Land use intensification in the humid tropics increased both alpha and beta diversity of soil bacteria. Ecology, 97: 2760-2771.

Chanway, C.P. 1997. Inoculation of tree roots with plant growth promoting soil bacteria: an emerging technology for reforestation. Forest Science, 43: 99-112.

Compant, S.; Clément, C.; Sessitsch, A. 2010. Plant growthpromoting bacteria in the rhizo-and endosphere of plants: their role, colonization, mechanisms involved and prospects for utilization. Soil Biology and Biochemistry, 42: 669-678.

Döbereiner, J.; Baldani, V.L.D.; Baldani, J.I. 1995. Como isolar e identificar bactérias diazotróficas de plantas não-leguminosas. Embrapa-SPI, Brasília, 60p.

EMBRAPA. 1997. Manual de métodos de análise de solos. 2nd. ed. Centro Nacional de Pesquisa de Solos, Rio de Janeiro, 212p.

Dollinger, J.; Jose, S. 2018. Agroforestry for soil health. Agroforestry Systems, 92: 213-219.

Estrada-De Los Santos, P.; Bustillos-Cristales, R.; Caballero-Mellado, J. 2001. Burkholderia a genus rich in plant-associated nitrogen fixers with wide environmental and geographic distribution. Applied and Environmental Microbiology, 67: 2790-2798.

Fankem, H.; Ngo Nkot, L.; Quinn, J.; Merbach, W.; Deubel, A.; Etoa, F.X.; Nwaga, D. 2008. Solubilization of inorganic phosphates and plant growth promotion by strains of Pseudomonas fluorescens isolated from acidic soils of Cameroon. African Journal of Microbiology Research, 2: 171-178.

FEMACT. 1993. O Brasil do hemisfério norte: diagnóstico cientifico e tecnológico para o desenvolvimento. Ed. Ambtec, Boa Vista, 512p.

Ferreira, D.F. 2011. Sisvar: a computer statistical analysis system. Ciência e Agrotecnologia, 35: 1039-1042.

Glick, B.R. 2012. Plant growth-promoting bacteria: mechanisms and applications. Scientifica, 2012: 1-15.

Guariguata, M.R.; Cronkleton, P.; Duchelle, A.E.; Zuidema, P.A. 2017. Revisiting the 'cornerstone of Amazonian conservation': a socioecological assessment of Brazil nut exploitation. Biodiversity and Conservation, 26: 2007-2027.

Hallmann, J.; Quadt-Hallmann, A.; Mahaffee, W.F.; Kloepper, J.W. 1997. Bacterial endophytes in agricultural crops. Canadian Journal of Microbiology, 43: 895-914. 
Hara, F.A.S.; Oliveira, L.A. 2004. Características fisiológicas e ecológicas de isolados de rizóbios oriundos de solos ácidos e álicos de Presidente Figueiredo, Amazonas. Acta Amazonica, 34: 343-357.

Hara, F.A.S.; Oliveira, L.A. 2005. Características fisiológicas e ecológicas de isolados de rizóbios oriundos de solos ácidos de Iranduba, Amazonas. Pesquisa Agropecuária Brasileira, 40: 667-672.

Illmer, P.; Barbato, A.; Schinner, F. 1995. Solubilization of hardly soluble $\mathrm{AlPO}_{4}$ with P-solubilizing microorganisms. Soil Biology and Biochemistry, 27: 265-270.

Jesus, E.C.; Marsh, T.L.; Tiedje, J.M.; Moreira, F.M.S. 2009. Changes in land use alter the structure of bacterial communities in Western Amazon soils. The ISME Journal 3: 1004-1011.

Kimura, M.A. 1980. Simple method for estimating evolutionary rate of base substitutions through comparative studies of nucleotide sequences. Journal of Molecular Evolution, 16: 111-120.

Lane, D.J. 1991. 16S/23S rRNA sequencing. In: Stackebrandt, E.; Goodfellow, M. (Ed) Nucleic acid techniques in bacterial systematics. Wiley, New York, p.115-175.

Long, H.H.; Schmidt, D.D.; Baldwin, I.T. 2008. Native bacterial endophytes promote host growth in a species-specific manner; phytohormone manipulations do not result in common growth responses. PLoS ONE, 3: e2702.

Lorenzi, A. 2002. Árvores brasileiras: manual de identificação e cultivos de plantas arbóreas do Brasil, v.1. Instituto Plantarum, Nova Odessa, 368p.

Marasco, R.; Rolli, E.; Ettoumi, B.; Vigani, G.; Mapelli, F.; Borin, S.; et al. 2012. A drought resistance-promoting microbiome is selected by root system under desert farming. PLoS ONE, 7: e48479.

Marra, L.; Oliveira, S.M.D.; Soares, C.R.F.S.; Moreira, F.M.D.S. 2011 Solubilization of inorganic phosphates by inoculant strains from tropical legumes. Scientia Agricola, 68: 603-609.

Marra, L.; Soares, C.R.F.S.; Oliveira, S.M.; Ferreira, P.A.A.; Soares, B.L.; Carvalho, R.F.; Lima, J.M.; Moreira, F.M.S. 2012. Biological nitrogen fixation and phosphate solubilization by bacteria isolated from tropical soils. Plant and Soil, 357: 289-307.

Moreira, F.M.S.; Gillis, M.; Pot, B.; Kersters, K.; Franco, A.A. 1993. Characterization of rhizobia isolated from different divergence groups of tropical Leguminosae by comparative gel electrophoresis of their total proteins. Systematic and Applied Microbiolgy, 16: 135-146.

Moreira, F.M.S.; Silva, K.; Nóbrega, R.S.A.; Carvalho, F. 2010. Bactérias diazotróficas associativas: diversidade, ecologia e potencial de aplicaçóes. Comunicata Scientiae, 1: 74-99.

Mori, S.A. 1992. The Brazil nut industry: past, present, and future. In: Plotkin, M.J.; Famolare, L.M. (Ed.). Sustainable Harvest and Marketing of Rainforest Products. Island Press, Washington, p.241-251.

Muller, C.H.; Fiqueiredo, F.J.C.; Kato, A.K.; Carvalho, J.E.U.; Stein, R.L.B.; Silva, A.B. 1995. Castanha-do-Brasil. Embrapa SPI, Brasília, 65p.
Murphy, J.; Riley, J.P. 1962. A modified single solution method for the determination of phosphate in natural waters. Analytica Chimica Acta, 27: 31-36.

Nautiyal, C.S. 1999. An efficient microbiological growth medium for screening phosphate solubilizing microorganisms. FEMS Microbiology Letters, 170: 265-270.

Neroni, R.F.; Cardoso, E.J.B. 2007. Occurrence of diazotrophic bacteria in Araucaria Angustifolia. Scientia Agricola, 64: 303-304.

Oliveira Junior, M.C.M.; Xaud, M.R.; Xaud, H.A.M.; Moura Neto, M.A.; Arco-Verde, M.F.; Pereira, P.R.V.S.; Tonini, H. 2003. Precipitação pluviométrica em áreas de transição savana-mata de Roraima: campos experimentais Serra da Prata e Confiança. Comunicado Técnico n ${ }^{\circ}$ 17. Embrapa Roraima, Boa Vista, 7p.

Oliveira-Longatti, S.M.; Marra, L.M.; Soares, B.L.; Bomfeti, C.A.; Silva, K.; Ferreira, P.A.A.; Moreira, F.M.S. 2014. Bacteria isolated from soils of the western Amazon and from rehabilitated bauxitemining areas have potential as plant growth promoters. World Journal of Microbiology and Biotechnology, 30: 1239-1250.

Ortiz, E. 2002. Brazil nut (Bertholletia excelsa). In: Shanley, P.; Pierce, A.R.; Laird, S.A.; Guillen, A. (Ed.). Tapping the green market: certification and management of non-timber forest products. Earthscan, London, p.61-74.

Pérez, E.; Sulbarán, M.; Ball, M.M.; Yarzábal, L.A. 2007. Isolation and characterization of mineral phosphate-solubilizing bacteria naturally colonizing a limonitic crust in the south-eastern Venezuelan region. Soil Biology and Biochemistry, 39: 2905-2914.

Pot, B.; Vandamme, P.; Kersters, K. 1994. Analysis of electrophoretic whole organism protein fingerprints. In: Goodfellow, M.; O'Donnell, A.G. (Ed.). Chemical methods in prokaryotic systematics. Wiley, New York, p.493-521.

Radwan, T.; Mohamed, Z.K.; Reis, V.M. 2002. Production of indole-3-acetic acid by different strains of Azospirillum and Herbaspirillum spp. Symbiosis, 32: 39-54.

Rodrigues Neto, J.; Malavolta Júnior, V.A.; Victor, O. 1986. Meio simples para o isolamento e cultivo de Xanthomonas campestris pv. citri tipo B. Summa Phytopathologica, 12: 16.

Santoyo, G.; Moreno-Hagelsieb, G.; Orozco-Mosqueda, M.C.; Glick, B.R. 2016. Plant growth-promoting bacterial endophytes. Microbiological Research, 183: 92-99.

Sarwar, M.; Kremer, R.J. 1995. Determination of bacterially derived auxins using a microplate method. Letters in Applied Microbiology, 20: 282-285.

Scott, A.J.; Knott, M.A. 1974. Cluster analysis method for grouping means in the analysis of variance. Biometrics, 30: 507-512.

SEPLAN. 2010. Informaçôes Socioeconômicas do Município de São João da Baliza-RR. CGEES/SEPLAN, Boa Vista, 68p.

Senthilkumar, M.; Govindasamy, V.; Annapurna, K. 2007. Role of antibiosis in suppression of charcoal rot disease by soybean endophyte Paenibacillus sp. HKA-15. Current Microbiology, 55: 25-29.

Silva, A.C.S.; Junior, A.F.C.; Oliveira, L.A.; Chagas, L.F.B. 2011 a. Ocorrência de bactérias solubilizadoras de fosfato nas raízes de plantas de importância econômica em Manaus e Rio Preto da Eva, Amazonas. Journal of Biotechnology and Biodiversity, 2: $37-42$. 
Silva Filho, G.N.; Narloch, C.; Scarf, R. 2002. Solubilização de fosfatos naturais por microrganismos isolados de cultivos de Pinus e Eucalyptus de Santa Catarina. Pesquisa Agropecuária Brasileira, 37: 847-854.

Silva Filho, G.N.; Vidor, C. 2000. Solubilização de fosfatos por microrganismos na presença de fontes de carbono. Revista Brasileira de Ciência do Solo, 24: 311-319.

Silva, K.; Cassetari, A.S.; Lima, A.S.; Brandt, E.; Pinnock, E.; Vandamme, P.; Moreira, F.M.S. 2012. Diazotrophic Burkholderia species isolated from the Amazon region exhibit phenotypical, functional and genetic diversity. Systematic and Applied Microbiology, 35: 253-262.

Silva, K.; Nóbrega, R.S.A.; Lima, A.S.; Barberi, A.; Moreira, F.M.S. 2011b. Density and diversity of diazotrophic bacteria isolated from Amazonian soils using N-free semi-solid media. Scientia Agricola, 68: 518-525.

Souza, R.; Ambrosini, A.; Passaglia, L.M.P. 2015. Plant growthpromoting bacteria as inoculants in agricultural soils. Genetics and Molecular Biology, 38: 401-419.

Spaepen, S.; Vanderleyden, J.; Okon, Y. 2009. Plant growthpromoting actions of rhizobacteria. In: Van Loon, L.C. (Ed.). Advances in Botanical Research. Academic Press, Burlington, p.283-320.

Tamura, K.; Peterson, D.; Peterson, N.; Stecher, G.; Nei, M.; Kumar, S. 2011. MEGA5: molecular evolutionary genetics analysis using maximum likelihood, evolutionary distance, and maximum parsimony methods. Molecular Biology and Evolution, 28: 2731-2739.
Thompson, J.D.; Higgins, D.G.; Gibson, T.J. 1994. CLUSTAL W: improving the sensitivity of progressive multiple sequence alignment through sequence weighting, position-specific gap penalties and weight matrix choice. Nucleic Acids Research, 22: 4673-4680.

Ueda, T.; Suga, Y.; Yahiro, N.; Matsuguchi, T. 1995. Genetic diversity of N2-fixing bacteria associated with rice roots by molecular evolutionary analysis of a nifD library. Canadian Journal of Microbiology, 41: 235-240.

Vale Júnior, J.F.; Leitão Sousa, M.I. 2005. Caracterização e distribuição dos solos das Savanas de Roraima. In: Barbosa, R.I.; Xaud, H.A.M.; Souza, J.M.C. (Ed.). Savanas de Roraima: Etnoecologia, biodiversidade e potencialidades agrosilvopastoris. FEMACT, Boa Vista, p.79-91.

Vessey, J.K. 2003. Plant growth promoting rhizobacteria as biofertilizers. Plant and Soil, 255: 571-586.

Vieira, S.; Trumbore, S.; Camargo, P.B.; Selhorst, D.; Chambers, J.Q.; Higuchi, N.; Martinelli, L.A. 2005. Slow growth rates of Amazonian trees: consequences for carbon cycling. Proceedings of the National Academy of Sciences of the United States of America, 102: 18502-18507.

Wadt, L.H.O.; Kainer, K.A.; Staudhammer, C.L.; Serrano, R.O.P. 2008. Sustainable forest use in Brazilian extractive reserves: natural regeneration of Brazil nut in exploited populations. Biological Conservation, 141: 332-346.

RECEIVED: $26 / 12 / 2018$

ACCEPTED: $21 / 08 / 2019$

ASSOCIATE EDITOR: Oscar Valverde 